\title{
Designing The Concepts - Framework \& The Maturity Level Of Smart Pondok Pesantren (Islamic Boarding Schools)
}

\author{
Sendi Novianto*1, Indra Gamayanto ${ }^{2}$ \\ Faculty of Computer Science, Universitas Dian Nuswantoro \\ E-mail : sendi.novianto@dsn.dinus.ac.id ${ }^{* 1}$, indra.gamayanto@dsn.dinus.ac.id ${ }^{2}$ \\ *Corresponding author \\ Farrikh Alzami ${ }^{3}$ \\ Faculty of Computer Science, Universitas Dian Nuswantoro \\ E-mail : alzami@dsn.dinus.ac.id ${ }^{3}$
}

Received 8 December 2015; Revised 10 February 2016; Accepted 2 March 2016

\begin{abstract}
The development of information technology and significant progress is happening today, where changes need to face increasingly high global competition. Islamic boarding schools are the centre of change, where boarding schools must develop four important factors: human resource development, information technology, culture and e-spirituality. This article is about developing smart city 3.0 and 5.0, where the resulting framework and methods can apply to Islamic boarding schools. Our research object is Islamic boarding schools, and in this place, we do community service. This article's results are the framework and the maturity level of smart Islamic boarding schools, where there are three indicators (people-culture, technologybusiness, implementation-global goals) and three important levels (stage 1-the foundation, stage 2-good foundation, stage 3-great foundation), which are the basis for developing a smart islamic boarding school. Moreover, this article is version 1.0, which in its development will extend to the application. An application Si-PenO (Online registration information system) completed at the Askhabul Kahfi Islamic boarding school as proof of applying the concept we created in this article. This change is needed to face globalization, and change is a good thing if it does systematically.
\end{abstract}

Keywords - Islamic boarding schools, Human resource development, Innovation, Framework, Information technology

\section{INTRODUCTION}

The term Pondok Pesantren (Islamic Boarding Schools) is two terms that show one meaning. According to its basic meaning, Pesantren is a place to study for students, while Pondok means a simple house or residence made of bamboo. Besides that, the word Pondok probably comes from the Arabic Funduq, which means a hostel or hotel. In Java, including Sunda and Madura, the terms Pondok and pesantren are generally used. Simultaneously, in Aceh, it is known as dayah or rangkang or menuasa, while in Minangkabau it is called surau. Islamic boarding schools in Indonesia have a very big role, both for the advancement of Islamic education and the Indonesian nation. Based on existing records, religious education activities in the archipelago started in 1596. These religious activities have become known as Islamic boarding schools. In a note in the notes of Howard M. Federspiel, one of the Islamic reviewers 
in Indonesia, by the 12th-century study centres in Aceh and Palembang (Sumatra), in East Java and Gowa (Sulawesi) had produced important writings. and has attracted students to study Islamic boarding schools are the centre of change, where Islamic boarding schools' development needed in globalization. Changes need to make so that Islamic boarding schools can contribute to society in the world. Things such as human resource development, application of information technology, cultural change, and enhancing spirituality are four important factors that must develop consistent because they can positively impact society. This article is the basic concept of smart city intelligence. This article will produce a framework and three levels in developing a boarding school called the maturity level of smart Pondok pesantren.

Furthermore, this article is an extension of the smart city 3.0 and 5.0 articles. The thing to understand is that this article is a long-term process, and this article is the first of several articles that will develop. The research object used in this article is the Islamic boarding school Askhabul kahfi, and we also do community service in that place.

Before we go any further into the discussion, some important matters such as culture and change and the application of technology need to be properly understood. Some of the literature says this, among others: (1) Culture defined as a shared belief, communication and patterns in a group of people who are in a certain area[1]; (2) Social skills are the individual's ability to interpret and manage social interactions[2]; (3) Organizational culture is a system that contains values, actions and beliefs[3]; (4) Organizational change is a discussion of time, interests, transformation, change and many other sides from a theoretical perspective that must discuss as a driving force for significant change [4]; (5) Cultural change must be a management goal because there are global changes from a strategic and operational perspective[5]; many factors influence (6) Culture, and this will determine whether the culture is good or not[6]; (7) Organizational culture is one of the most significant realistic characteristics found in organizations [7]. An explanation of culture from several literature reviews shows that change needs in the face of significant global changes. Furthermore, we must also understand the technology and its application; some literature explains it as follows: (1) Rapid change is a presence of innovation and technology[8]; (2) In the field of technology, the adoption of innovative technology is very important and must be done[9]; (3) Using technology is the full power of communication to make innovation[10]; (4) Technology is a big leap that changes everything to be more effective and efficient[11]; (5) Innovation develops into new ideas, products, services and processes that utilize technology. It is very important to build so that organizations can advance in the face of globalization [12]; (6) The nature of technology is a change in the social economy, and this will continue to grow[13]; (7) Smart economy can be measured by productivity and adaptation to change[14]. The explanation of the technology and its application also shows that information technology is an infrastructure facility that must build quickly to implement these changes immediately. We also have to understand the context and content of Islamic boarding schools which are closely related to smart cities, therefore, there are several understandings about smart cities from the literature, including: (1) The basic elements of a smart city are smart economy, smart government, smart people, smart living, and smart environment[15]; (2) "Smart City" may be defined as a "city of knowledge," "digital city," "cyber city" or "eco-city" - according to the urban planning[16]; (3) Urban planning based on smart city concept should have various e-service portfolios such as: E-government services, Edemocracy services, E-Business services, E-health and tele-care services, E-learning services, ESecurity services, Environmental services, Intelligent Transportation, and Communication services[17]; (4) Smart city: hard and soft facility[18]; (5) The smart city concept originated from various definitions including those of the "intelligent city", "information city", "knowledge city", "digital city" and "ubiquitous city". It also has something in common with such notions as 'creative city', 'green city' and 'clever city'[19]; (6) The concept of a smart city is relatively new 
and can be seen as a successor of information city, digital city and sustainable city[20]; (7) A city "connecting the physical infrastructure, the information-technology infrastructure, the social infrastructure, and the business infrastructure to leverage the collective intelligence of the city"[21]; (8) A city striving to make itself "smarter" (more efficient, sustainable, equitable, and livable)[22]. From this explanation, we can understand that smart cities must apply to Islamic boarding schools to increase competitiveness and competence in the face of globalization.

\section{RESEARCH METHOD}

\subsection{The Process of research}

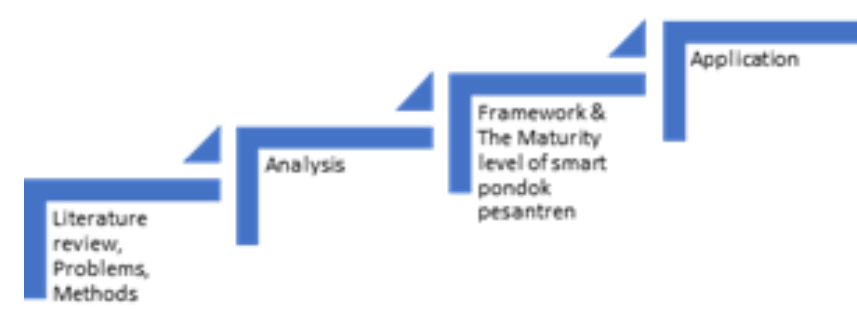

Figure 1. The process of research- Islamic boarding schools (Smart Pondok Pesantren)

Figure 1 describes the stages carried out on the development of smart boarding schools. The first stage is to conduct a literature review and analysis of the problem and method. The method used here is a smart city, 3.0 and 5.0[23],[24]. The second stage analyses these problems and produces innovation, which is continued in the third stage, namely the smart boarding school framework and the maturity level. The last stage is the application or software. In the application section, this will do in the long term after the concept of smart Pondok pesantren completed to create an application and several things needed to develop a smart Pondok pesantren (Islamic boarding schools).

\subsection{Data set}

Data collection on Islamic boarding schools includes Islamic boarding schools, the Equality Education Program (Packages A, B, C), the 9-year Basic Education Program at the Salafiyah Islamic Boarding School. The data collection for Islamic boarding schools education institutions for the 2011-2012 academic year covers 33 provinces. The data collection for Islamic boarding schools for 2011-2012 has successfully recorded 27,230 Islamic boarding schools throughout Indonesia[25],[26].

The largest Islamic boarding schools population is in West Java, East Java, Central Java and Banten, amounting to $78.60 \%$ of the total number of Islamic boarding schools in Indonesia. With details of West Java 7,624 (28.00\%), East Java 6,003 (22.05\%), Central Java 4,276 (15.70\%), and Banten 3,500 (12.85\%). Of all the existing Islamic boarding schools, based on the typology of Islamic boarding schools, there were 14,459 (53.10\%) Salafiyah Islamic boarding schools, 7,727 (28.38\%) Khalafiyah / Ashriyah and 5,044 (18.52\%) combined Islamic boarding schools. The total number of Islamic boarding schools students is 3,759,198 students, consisting of $1,886,748$ male students $(50.19 \%)$, and $1,872,450$ female students $(49.81 \%)$. The total number of Islamic boarding school teachers is 153,276 , consisting of $102,495(66.87 \%)$ male teachers and $50,781(33.13 \%)$ female teachers[25],[26] 


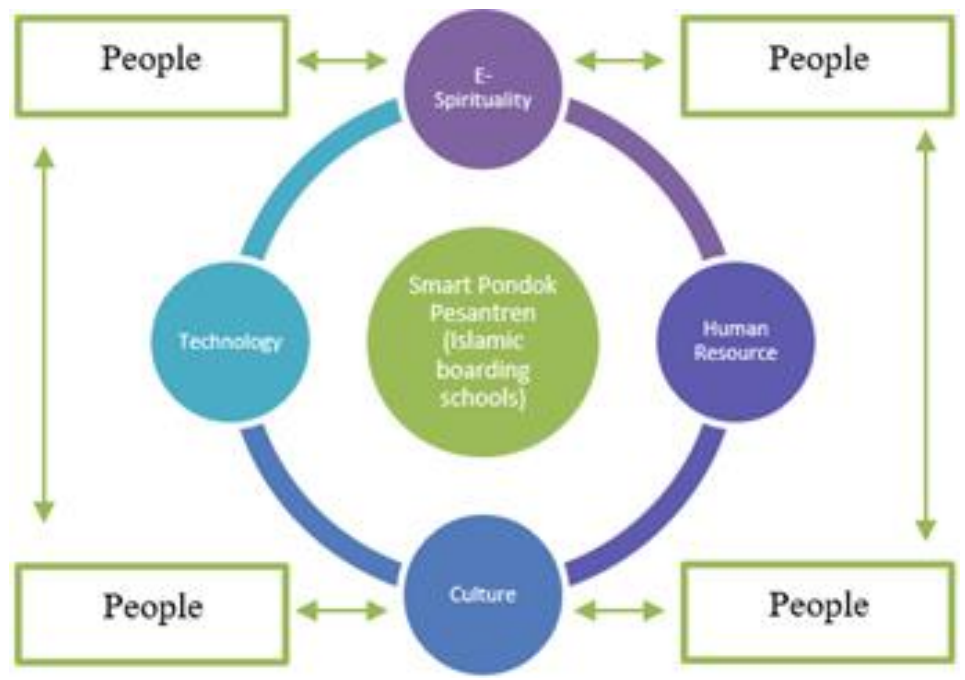

Figure 2. Framework Smart Pondok Pesantren (Islamic boarding schools)

In this framework, there are four important parts, among others: E-Spirituality, Human resource, culture, technology, and there are four important supporting things: people, habits, business policy. These eight parts should not be separated from each other and may not be developed separately but must build it. For example, if the only infrastructure built with building facilities and sophisticated technology is available, but there is no human resource development in Islamic boarding schools, there will be an imbalance and vice versa. The explanation of this framework is as follows:

The first thing that must develop is the habit of discipline, order and other positive things related to Islamic religious values. The santri and santriwati must be able to obey the rules and regulations set out in the boarding school and must implement them consistently to result in habits in behaviour and mindset that have been built consistently from habitual discipline. It is useful in producing santri and santriwati who will become role models for society in many positive ways, such as deeds, words and other things that result from Islamic religious values that applied in everyday life. This discipline will also produce a more positive culture in the boarding school, and this impact will produce positive things for the people who live around the boarding school. Furthermore, it will produce Islamic leaders who can make a positive contribution to society in the world[27],[28],[29]. Casely, Ato Coleman said: Globalization, restructuring, and technological developments affect the organization's entire course. In this case, human resources play a role in this dynamic change, and the right flow of information must do so that organizations can develop towards globalization [30]. Regarding culture, some experts say: (1) Dr Nyameh Jerome: Organizational culture must see from a cause and effect perspective[31], (2) Derek Crews: Culture can affect services, quality, productivity and finances[32], (3) Osibanjo Omotayo Adewale: Organizational culture arises from the influence of national culture and previous events, $p$. this will create a dynamic in personality and socialization which is also influenced by the past[33], (4) Biljana Bogićević Milikić: Culture requires an approach to managing people[34]

The second thing is the application of information technology in Islamic boarding schools. This technology must implement and developed significantly[35]. For example, Islamic boarding schools can use technology in the learning process and daily activities. The technology must speed up a process, and supervision must carry out so that students and female students can use technology appropriately. Technology will also help support entrepreneurship and business development programs at regional, national and international levels[36]. 
The third thing is the policy. In this section, Islamic boarding schools must comply with the central government's rules and regulations so that everything can run well. Of course, Islamic boarding schools provide input to the central government in developing policies so that positive things can create between the central government and Islamic boarding schools. For example, the central government provides input on what support can provide so that Islamic boarding schools can increase their competence. Moreover, they can contribute to and improve people's living standards in their regions or positively impact and contribute to the world community[37],[38].

\section{RESULTS AND DISCUSSION}

\subsection{The Maturity Level Of Smart Pondok Pesantren}

Table.1. The Maturity level of smart Pondok Pesantren (Islamic Boarding Schools)

\begin{tabular}{|c|c|c|c|}
\hline $\begin{array}{c}\text { Stage } \\
\text { Indicator }\end{array}$ & $\begin{array}{c}\text { Stage } 1 \\
\text { The Foundation }\end{array}$ & $\begin{array}{c}\text { Stage } 2 \\
\text { Good Foundation }\end{array}$ & $\begin{array}{c}\text { Stage } 3 \\
\text { Great Foundation }\end{array}$ \\
\hline People-Culture & $\begin{array}{c}\text { Dicipline, Customs, } \\
\text { Bachelor Degree, } \\
\text { Training }\end{array}$ & $\begin{array}{l}\text { Master Degree, } \\
\text { Business at an } \\
\text { intermedia }\end{array}$ & $\begin{array}{c}\text { PhD, Business at } \\
\text { national / international } \\
\text { level, International } \\
\text { certificate } \\
\end{array}$ \\
\hline Technology - Business & $\begin{array}{l}\text { Use of Computers in } \\
\text { Islamic boarding } \\
\text { schools human } \\
\text { resources and } \\
\text { competence }\end{array}$ & $\begin{array}{c}\text { Mentoring, } \\
\text { technology } \\
\text { integration, local } \\
\text { level business } \\
\text { development } \\
\end{array}$ & $\begin{array}{c}\text { National and } \\
\text { International } \\
\text { integration, national } \\
\text { and international } \\
\text { business development }\end{array}$ \\
\hline Implementation - Global Goals & $\begin{array}{l}\text { Infrastructure, } \\
\text { University cooperation } \\
\text { at the regional level }\end{array}$ & $\begin{array}{l}\text { Mentor, national- } \\
\text { level university } \\
\text { cooperation, } \\
\text { cooperation with } \\
\text { national-level } \\
\text { companies }\end{array}$ & $\begin{array}{l}\text { University cooperation } \\
\text { at the international } \\
\text { level, cooperation with } \\
\text { international companies }\end{array}$ \\
\hline
\end{tabular}

Table 1 describes the two stages in developing a smart Pondok pesantren. The first stage is the smart Pondok pesantren framework, and the second stage is the maturity level of smart Pondok pesantren (The three stages of smart Pondok pesantren).

3.1.2. The Maturity Level Of Smart Pondok Pesantren (Islamic boarding schools) (The Tree Stages Of Smart Pondok Pesantren (Islamic boarding schools)

\subsubsection{People-culture}

\subsection{Indicator 1 \& Stage 1: Discipline, Customs, Bachelor Degree, Training.}

In stage 1, the initial foundation built consistently because this will become the basis for the next process. Islamic boarding schools first build good habits in terms of discipline with what has been set by the boarding school and must build competence with a minimum level of bachelor's degree. For this, mastery of several languages must also be supported, including English that must master well, plus other languages that can choose one or two as supporting competencies: Mandarin, Japanese or Korean. Training must also include technical training and obtaining certificates. The training should not be one day but have quality training such as database training for three months, networking for one month or programming for six months. It is to be mean and true in terms of training, not just focusing on getting a certificate but improving one's abilities. 
At this early stage, Islamic boarding schools can start looking for mentors or people who have to provide guidance or support in increasing human resources competence in Islamic boarding schools. Reza Alami said: New management techniques can increase the effectiveness of human resources[39]

3.1.2.1.2. Indicator 1 \& Stage 2: Master Degree, Business at an intermediate level, National certificate

The Islamic boarding schools then developed further. At this level, the santri and santriwati upgraded to become more focused in specialization in certain fields. It is useful for increasing competence and increasing global competitiveness. Islamic boarding schools can collaborate with several universities at the regional level. When they have graduated, they can return to their respective regions to build a business or contribute usefully to improve the people's living standards in the area. Training must still carry out to increase competency at a higher level by obtaining some intermediate training, after which businesses can also start building at the regional level.

3.1.2.1.3. Indicator 1 \& Stage 3: Ph.D, Business at the national / international level, International certificate

Level three is the final stage to meet the requirements at this level. At this level, students and students improve their competence by obtaining a doctor of philosophy education and accompanied by several advanced level certificates so that their competence and specialization can be truly focused. Collaboration with several universities at the national or international level can also be done and build a business on a national scale. In the long term, a Sharia-based and general-based business can build[40].

\subsubsection{Technology-Business}

3.1.2.2.1. Indicator 2 \& Stage 1: Use of computers in Islamic boarding schools, human resources and competence

This section, it still connected with stage 1 on indicator 1 . Islamic boarding schools must have computers and technology to increase positive habits using information technology accompanied by increased competence. Human resources in Islamic boarding schools must be based on human technology, meaning that technology is more effective and efficient. That competence can be high-level thinking and high-level character.

3.1.2.2.2. Indicator 2 \& Stage 2: Mentoring, Technology integration, Regional business development

Mentoring must run on stage 2, where mentors can come from Sharia-based business practitioners or, in general, this is useful for contributing to Islamic boarding schools. In this case, it will be possible to apply profit sharing with Islamic boarding schools when a santri or santriwati successfully builds a business at the regional level. Integration can also do with other Islamic boarding schools and several local or national level companies to increase profits on Islamic boarding schools, income in the area, and the central government.

3.1.2.2.3. Indicator $2 \&$ Stage 3: Integration at the national and international levels, national and international business development.

Stage 3 is the highest level of integration and competence. Islamic boarding schools can work together in increasing brand, promotion, positioning. From here, it will continue to develop to the international level and cooperate with international companies. Mentoring can also 
improve by using international level mentors to develop entrepreneurial-based smart boarding schools.

\subsubsection{Implementation-Global Goals}

3.1.2.3.1. Indicator 3 \& Stage 1: Infrastructure, University cooperation at the regional level

This stage is the implementation stage; infrastructure must build technology, human resources, and competencies to meet the requirements. It is associated with indicators 1,2 and stage 1

3.1.2.3.2. Indicator 3 \& Stage 2: Mentors, National level university cooperation, cooperation with national-level companies.

This stage is associated with indicators 1,2 and stage 2

3.1.2.3.3. Indicator 3 \& Stage 3: University cooperation at the international level, cooperation with international companies.

This stage is associated with indicators 1,2 and stage 3

How to apply the framework and the maturity level of Islamic boarding schools to be more effective and efficient and have a business process that can run in a structured and systematic manner? Next, I will explain using a case study simulation with three patterns: Islamic boarding school type A, Islamic boarding schools type B and Islamic boarding schools type C.

\subsection{Case study analysis - Islamic Boarding Schools Types}

3.2.1. case study A- Islamic boarding schools Type A

Islamic boarding schools type A has the following description:

Table.2. Simulation of Islamic boarding school type A

\begin{tabular}{|l|l|l|l|}
\hline $\begin{array}{l}\text { Indicator \& } \\
\text { Stage }\end{array}$ & Stage 1 & Stage 2 & Stage 3 \\
\hline People - culture & & & It's done \\
\hline $\begin{array}{l}\text { Technology - } \\
\text { Business }\end{array}$ & & & It's done \\
\hline Implementation & & & It's done \\
\hline
\end{tabular}

Table 2 explains that Islamic boarding schools type $A$ is an Islamic boarding school that has reached stage 3 and fulfils all the maturity level requirements, so this is already very good and only needs to maintain and continue to develop things that are requirements of the maturity level to contribute to society. But the question is, is it only up to this position, and what can Islamic boarding schools type A do? type A can help develop Islamic boarding schools' types A1, A2, A3. It can describe as follows: 


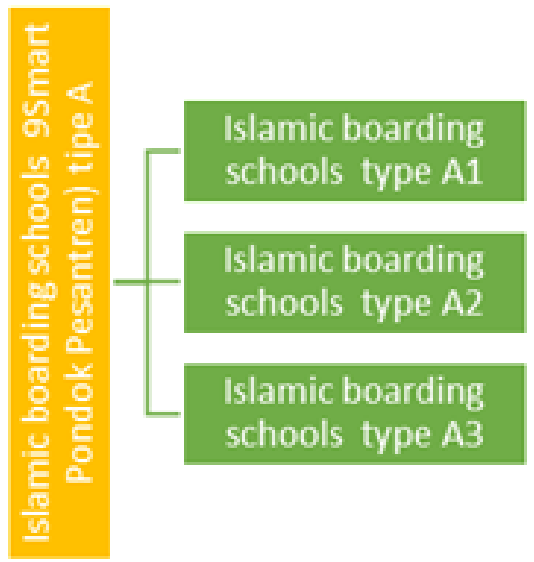

Figure 3. The integration of smart boarding school type $A$ with $A 1, A 2, A 3$

Figure 3 explains, the Islamic boarding school type A already has very high capabilities by being on stage 3 . Of course, there is one Islamic boarding school in this area, and in the nearby areas, there are other Islamic boarding schools. Therefore, type A can help develop Islamic boarding schools types $A 1, A 2, A 3$. For example, type $A 1$ still lacks human resources, so type $A$ can assist in training and human resource development for type A1. Type A2 lacks facilities or infrastructure in terms of technology, so type $A$ can lend its facilities to type $A 2$ and collaborate to develop infrastructure type $A 2$ with the financial system discussed with type A2. Type A3 still lacks human resources and infrastructure, so type $A$ can provide mentoring so that type $A 3$ can achieve both of these things and provide input as a consultant so that type $A 3$ can reach a higher stage.

\subsection{2. case study B- Islamic boarding schools Type B}

Table 3. Islamic boarding schools type B

\begin{tabular}{|l|l|l|l|}
\hline $\begin{array}{l}\text { Indicator \& } \\
\text { Stage }\end{array}$ & Stage 1 & Stage 2 & Stage 3 \\
\hline People - culture & & & \\
\hline $\begin{array}{l}\text { Technology - } \\
\text { Business }\end{array}$ & & It's done & \\
\hline Implementation & & It's done & \\
\hline
\end{tabular}

Table 3 explains that Type B is a smart type of boarding school type for medium, where type B successfully builds people $\&$ culture indicators, and implementation reaches maturity stage 3. It means that human resource competence achieved and capabilities improved with a consistent process. But if you look at table 2, the technology-business and implementation indicators have only reached stage 2 . How do you increase it to stage 3 ? There are two events, including collaborating with Islamic boarding schools that have reached stage 3 or increasing indicators 2 and 3 by themselves until they reach stage 3 by collaborating with local governments or companies at the national/international level for a significant increase. 


\subsection{3. case study C- Islamic boarding schools Type C}

Table .4. Islamic boarding schools type C

\begin{tabular}{|l|l|l|l|}
\hline $\begin{array}{l}\text { Indicator \& } \\
\text { Stage }\end{array}$ & Stage 1 & Stage 2 & Stage 3 \\
\hline People - culture & & It's done & \\
\hline $\begin{array}{l}\text { Technology - } \\
\text { Business }\end{array}$ & It's done & & \\
\hline Implementation & It's done & & \\
\hline
\end{tabular}

Table 4 explains that Islamic boarding schools reach stage 2 on indicator only reaches stage 1 on indicators 2 and 3. How do you achieve increasing the maturity level? Type C must first balance the increase in indicators 1 and 2 until it reaches stage 2, meaning that stage 2 must be maintained and should not go down to stage 1 . In indicator 2, type $\mathrm{C}$ must increase it until it reaches stage 2 , as well as in indicator 3 , Type $\mathrm{C}$ can collaborate with Islamic boarding schools that have reached stage 3 , can also attract investors into Islamic boarding schools or can also collaborate with local governments and / companies at the national level.

The question is: how to improve the simulation so that it can reach stage 3 , especially in types B and C. Type A has reached stage 3 , so what is needed is to maintain and continue to develop it. The following framework will describe the integration between Islamic boarding schools and increase the impact, such as connecting networks with one another.

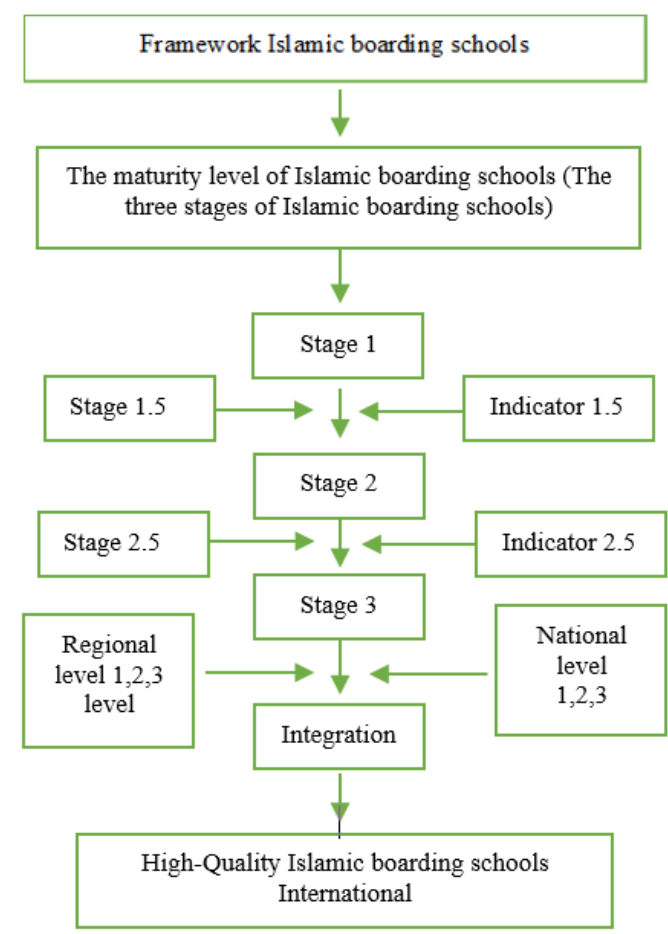

Figure 4. Framework \& The maturity level of Islamic boarding schools- Implementation Step By Step

Figure 4 explains the stages of implementing the framework and the maturity level of smart boarding schools carried out in stages. The improvement is done not directly from stage 1 to stage 2 or stage 2 to stage 3 but is carried out gradually and in more detail in its application.

The first stage: analysis of the Islamic boarding school using the boarding smart boarding school. Does the boarding school meet the requirements contained in the framework? Do 
Islamic boarding schools have stable people and culture? Has the application or use of information technology in these Islamic boarding schools been implemented effectively and efficiently? And does this implementation already have standard operating procedures that can execute properly ?. If one of these indicators not meet, it can say that the boarding school has not reached level 1 , but it is still running manually, and there are no indicators and stages that can apply. Islamic boarding schools must first fulfil the framework's requirements and table the minimum maturity level of Islamic boarding schools on stage 1 . Now we will explain how to increase the stage in more detail but on the condition that the boarding school meets the requirement stage 1.

Islamic boarding schools that have met the requirement in stage 1 can be said to be smart boarding schools because indicators 1-3 fulfilled, and the main thing that needs to do is upgrade to stages 2 and 3 . Islamic boarding schools can first increase the indicators and stages for each. Fifty per cent level, meaning stage 1 to stage 1.5 , and so on. The most important thing here is to be consistent in improving this and determining the short, medium. Long term in increasing the stage. for example, when an Islamic boarding school wants to increase stage 1 of human resources, then, on the other hand, Islamic boarding schools must also improve these technological facilities in a smart boarding school because if the resources are available. The infrastructure is not ready. It will not reach the maximum and increase in level, and vice versa; if the technological infrastructure is available, but there are no competent human resources, it will waste time and money. Balance is the key; balance in each stage needs to be maintained. When increasing the stage, it is necessary to determine which priorities need to improve in the short term and what indicators can do in the medium term and long term implementation with a certain time limit. This development must determine a time and must complete within a specified time; if you go back one step, then the thing that happens is that the stage increase will run slowly. A standard operating procedure must make so that Islamic boarding schools have guidelines in implementing the framework and the maturity level of Islamic boarding schools. Document every process that carried out, and if there is an error in carrying out the stage warning process, then return it to the standard operating procedures that created. It will quickly make improvements to the process and quickly solve problems. At stage 2, the same thing done; if the boarding school wants to increase the existing stage, it can be done slowly as in stage 1. The most important thing is the next process is when the Islamic boarding schools have passed stages 1-3, it must be able to strengthen its position at the regional level, then upgraded to the national and international levels, in other words, the regional level is a short term that must achieve by Islamic boarding schools, the national level in the medium-term target and international level is long term, with duration: regional level (1-3 years), national level (3-5 years), and international level (5-7 years).

The research will continue to develop because it only covers concepts and creates a conceptual foundation for Islamic boarding schools. It reached the endpoint, namely the Islamic boarding schools application, which includes several things tailored to smart boarding schools' needs.

\section{CONCLUSION}

The results of the article can be summarized as follows:

1. Islamic boarding schools require changes in the face of globalization by turning into smart Islamic boarding schools by developing those that meet the standards first, which contained in the smart Pondok pesantren framework.

2. The maturity level of Islamic boarding schools (The three stages of Islamic boarding schools) is a method that can increase the Islamic boarding schools maturity level. 
3. There is integration between other Islamic boarding schools and the central government, local governments, companies at the regional, national and international levels to increase competitiveness in facing current global developments by establishing businesses in their regions up to the national/international level.

\section{REFERENCES}

[1] W. P. Onyango, "Effects of Organization Culture on Change Management: A Case of the Vocational Training Centre for the Blind and Deaf Sikri," Eur. J. Bus. Manag., vol. 6, no. 34, pp. 2222-2839, 2014, [Online]. Available: http://www.iiste.org/Journals/index.php/EJBM/article/viewFile/17157/18008.

[2] S. Y. Wu, D. B. Turban, and Y. H. Cheung, "Social skill in workplace mentoring relationships," J. Organ. Cult. Commun. Confl., vol. 16, no. 2, pp. 61-72, 2012.

[3] J. Suwaryo, H. K. K. Daryanto, and A. Maulana, "Organizational Culture Change and its Effect on Change Readiness through Organizational Commitment," Bisnis Birokrasi J., vol. 22, no. 1, 2016, DOI: 10.20476/jbb.v22i1.5431.

[4] M. Alvesson and S. Sveningsson, Changing organizational culture: Cultural change work in progress. 2007.

[5] R. K. Smollan and J. G. Sayers, "Organizational Culture, Change and Emotions: A Qualitative Study," J. Chang. Manag., vol. 9, no. 4, pp. 435-457, 2009, DOI: 10.1080/14697010903360632.

[6] S. K. Tran, "GOOGLE: a reflection of culture, leader, and management," Int. J. Corp. Soc. Responsib., vol. 2, no. 1, 2017, DOI: 10.1186/s40991-017-0021-0.

[7] C. Whelan, "Organizational culture and cultural change: A network perspective," Aust. New Zeal. J. Criminol., vol. 49, no. 4, pp. 583-599, 2016, doi: 10.1177/0004865815604196.

[8] S. Wadood, B. Gharleghi, and B. Samadi, "Influence of Change in Management in Technological Enterprises," Procedia Econ. Financ., vol. 37, no. 16, pp. 129-136, 2016, DOI: 10.1016/s2212-5671(16)30103-4.

[9] D. V. Chulkov, "On the Role of Switching Costs and Decision Reversibility in Information Technology Adoption and Investment," J. Inf. Syst. Technol. Manag., vol. 14, no. 3, pp. 309-321, 2017, DOI: 10.4301/s1807-17752017000300001.

[10] J. Clarke-Midura and C. Dede, "Assessment, technology, and change," J. Res. Technol. Educ., vol. 42, no. 3, pp. 309-328, 2010, DOI: 10.1080/15391523.2010.10782553.

[11] J. Sheoran, "Technological Advancement and Changing Paradigm of Organizational Communication," Int. J. Sci. Res. Publ., vol. 2, no. 1, pp. 2250-3153, 2012, [Online]. Available: www.ijsrp.org.

[12] A. P. Ndesaulwa, "The Impact of Technology and Innovation (Technovation) in Developing Countries: A Review of Empirical Evidence," J. Bus. Manag. Sci., vol. 4, no. 1, pp. 7-11, 2016, DOI: 10.12691/jbms-4-1-2.

[13] B. Lowe, Y. Dwivedi, and S. P. D'Alessandro, "Consumers and Technology in a Changing World," Eur. J. Mark., vol. 53, no. 6, pp. 1038-1050, 2019, DOI: 10.1108/EJM-06-2019966.

[14] J. Winkowska, D. Szpilko, and S. Pejić, "Smart city concept in the light of the literature review," Eng. Manag. Prod. Serv., vol. 11, no. 2, 2019.

[15] D. T. ILIĆ, B. M. MARKOVIĆ, and N. KRASULA, "smart city: a contemporary concept of sustainable urban development," J. Chem. Inf. Model., vol. 9, no. 1 (21), 2020.

[16] R. A. Shichiyakh, D. A. Klyuchnikov, S. P. Balashova, S. N. Novoselov, and N. N. Novosyolova, "Smart city as the basic construct of the socio-economic development of territories," Int. J. Econ. Financ. Issues, vol. 6, no. 1S, pp. 157-162, 2016. 
[17] M. Bakri and A. A. Kasim, "The Urban Planning Concept Based on Smart City Approach," Int. J. Livable Sp., vol. 3, no. 2, p. 63, 2018, DOI: 10.25105/livas.v3i2.3014.

[18] X. Chen, "The development trend and practical innovation of smart cities under the integration of new technologies," Front. Eng. Manag., vol. 6, no. 4, pp. 485-502, 2019, DOI: 10.1007/s42524-019-0057-9.

[19] M. Kola-Bezka, M. Czupich, and A. Ignasiak-Szulc, "Smart cities in central and Eastern Europe: Viable future or unfulfilled dream?," J. Int. Stud., vol. 9, no. 1, pp. 76-87, 2016, DOI: 10.14254/2071-8330.2016/9-1/6.

[20] E. P. Trindade, M. P. F. Hinnig, E. M. da Costa, J. S. Marques, R. C. Bastos, and T. Yigitcanlar, "Sustainable development of smart cities: A systematic review of the literature," J. Open Innov. Technol. Mark. Complex., vol. 3, no. 3, 2017, DOI: 10.1186/s40852-017-0063-2.

[21] S. P. Mohanty, U. Choppali, and E. Kougianos, "Everything you wanted to know about smart cities," IEEE Consum. Electron. Mag., vol. 5, no. 3, pp. 60-70, 2016, DOI: 10.1109/MCE.2016.2556879.

[22] M. S. H. Ansari and M. Mehrotra, "Development of smart cities and its sustainability: A smart city framework," Int. J. Innov. Technol. Explor. Eng., vol. 8, no. 11, pp. 646-655, 2019, DOI: 10.35940/ijitee.K1703.0881119.

[23] S. Wibowo and I. Gamayanto, "Konsep dan Strategi Pengembangan Smart Regional (Smart City) Dalam Menghadapi Globalisasi Version 3.0 Dengan Menggunakan Metode PDCA \& USEPDSA," J. Litbang Kota Pekalongan, vol. 17, no. 1, pp. 44-53, 2019.

[24] A. Nurhindarto and I. Gamayanto, "Developing Smart City 5 . 0 Framework to Produce Competency," J. Appl. Intell. Syst., vol. 5, no. 1, pp. 23-31, 2020.

[25] Departemen Agama RI, "Analisis Statistik Data Pendidikan Islam," 2008.

[26] Kementrian Agama Republik Indonesia, "Analisis dan Interpretasi Data pada Pondok Pesantren , Madrasah Diniyah ( Madin ), Taman Pendidikan Qur' an ( TPQ ) Tahun Pelajaran 2011-2012," 2012.

[27] A. Tolib, "Pendidikan Di Pondok Pesantren Modern Terpadu," Risalah, vol. 1, no. 1, pp. 60-66, 2015.

[28] A. B. Tamam, "MODEL PENELITIAN TAFSIR; STUDI KARYA HOWARD M . FEDERSPIEL ' Popular Indonesian Literature Of The Qur'an ,'" Madinah J. Stud. Islam, vol. 5, no. 2, pp. 125-138, 2018.

[29] F. W. Rohmiyati, "THE ROLE OF SCHOOL PRINCIPAL IN THE MINDSET FORMATION (Analysis Study at Islamic Kindergarten Tunas Melati Yogyakarta)," J. IIm. Pesantren, vol. 5, no. 2, pp. 741-754, 2019.

[30] C. Coleman Ato, "The Role of HR in Organizational Culture and Knowledge Management," Open J. Hum. Resour. Manag., vol. 1, no. 2, pp. 22-43, 2018.

[31] N. Jerome, "Empirical Investigation of the Impact of Organizational Culture on Human Resource Management," Int. J. Bus. Soc. Sci., vol. 4, no. 5, pp. 84-93, 2013.

[32] D. Crews and S. Richard, "Aligning culture with human resource strategies," Int. J. Bus. Soc. Sci., vol. 4, no. 15, pp. 71-75, 2013.

[33] A. O. Osibanjo and A. A. Adeniji, "Impact of Organizational Culture on Human Resource Practices: A Study of Selected Nigerian Private Universities," J. Compet., vol. 5, no. 4, pp. 115-133, 2013, DOI: 10.7441/joc.2013.04.07.

[34] B. B. Milikić, "The influence of culture on human resource management processes and practices: The propositions for Serbia," Econ. Ann., vol. 54, no. 181, pp. 93-118, 2009, DOI: 10.2298/EKA0981093B.

[35] B. M. Alwi, "Pondok Pesantren: Ciri Khas, Perkembangan, Dan Sistem Pendidikannya," Lentera Pendidik. J. Ilmu Tarb. dan Kegur., vol. 16, no. 2, pp. 205-219, 2016, doi: 


\subsection{2/Ip.2013v16n2a8.}

[36] M. 'Aliyah, "Knowledge Management Sebagai Upaya Pengembangan Learning Organization Di Pondok Pesantren Mahasiswa Al-Muayyad Windan," J. IIm. Pesantren, vol. Vol 6, no. 2, pp. 729-740, 2020.

[37] K. Khasanah, M. Muhlas, and L. Marwani, "Development of E-Learning Smart Apps Creator (Sac) Learning Media for Selling Employees on Paid Tv," Akademika, vol. 9, no. 02, pp. 129-143, 2020, doi: 10.34005/akademika.v9i02.819.

[38] C. E. W. Utomo and M. Hariadi, "Strategi Pembangunan Smart City dan Tantangannya bagi Masyarakat Kota," J. Strateg. dan Bisnis Vol.4, vol. 4, no. 2, pp. 159-176, 2016.

[39] R. Alami et al., "The Effectiveness of Human Resource Management on Improving the Performance," Int. J. Bus. Soc. Sci., vol. 6, no. 5, pp. 251-254, 2015.

[40] Albert Sangra, Dimitrios Vlachopoulos, and Nati Cabrera, "Building an inclusive definition of e-learning: An approach to the conceptual framework," Int. Rev. Res. Open Distance Learn., vol. 13, pp. 145-159, 2012. 